\title{
The Effect of Teaching CoRT Program No. (4) Entitled "Creativity" on the Gifted Learners' Writings in Ein El-Basha Center for Gifted Students
}

\author{
Oraib Hmoud Al-Faoury \\ Faculty of Languages and Translation, Imam Muhammad ibn Saud Islamic University, Riyadh, KSA
}

Faisal Khwaileh

Dept. of Curriculum and Instruction, the University of Jordan, Amman, Jordan

\begin{abstract}
This study attempts to investigate the effect of teaching CoRT Program 4 entitled "Creativity" on the gifted learners' creative abilities in writing. The sample consisted of $\mathbf{3 6}$ gifted students in Ein El-Basha Center for Gifted Students. The first group ( $N=18$ ) was the control group (male and female students). The second group ( $\mathrm{N}=18$ ) was the experimental group (male and female students).A pretest measuring fluency, flexibility and originality was administered for both groups. While CoRT program was demonstrated through 20 sessions taught for a period of three months for the experimental group, the control group continued studying in the traditional way. The test was validated and its interscorer reliability was ensured. The results of the study showed that the mean score of the experimental group was significantly higher than the mean score of the control group on fluency, flexibility and originality which indicates that the CoRT Program No. 4 entitled "Creativity" developed the gifted learners' creative abilities in writing English short stories. In light of the results of the study, the researcher recommends providing the gifted students with CoRT No. 4 entitled "Creativity" that could stimulate their fluency, flexibility and originality to write short stories creatively.
\end{abstract}

Index Terms-EFL, CoRT, gifted students, short story, Jordan

\section{INTRODUCTION}

In the Information Age, it is important to create opportunities for the learners which stimulate them to learn and make use of the new information in order to understand the amount of knowledge growing rapidly (Cotton, 1997; Presseisen, 1988). Newton (2000) warns against the bad consequences of the traditional syllabuses which lack high teaching abilities by saying "The result, of course, is a student who cannot respond flexibly, cannot think critically or creatively and who has acquired habits of minds that put more weight on the quantity of knowledge than the quality of understanding developed" (p.181).

Curriculum specialists in Jordan prepared a plan (The Educational Development Plan) in 1987 in which they emphasized the importance of teaching thinking. The Law of Education mandated in 1964 and 1994 emphasized the importance of teaching thinking skills. The General Framework for Curricula and Evaluation, issued by the Ministry of Education (MOE) in 2003, indicated the importance of revealing students' creativity and evaluating their creative works.

Many educators emphasize the tremendous advantages for teaching thinking skills too. However, scholars (see, for example, Al-Hishoush, 2006; El- Mustafa, 1988; Karsou, 2005; Saleh, 1990) evaluated English series textbooks, which were taught since 1985 and still taught till now, and reported that there is still an urgent need to develop higher thinking skills in English language syllabuses in order to help students face the new challenges.

Edward Debono (2004) wrote CoRT, which stands for Cognitive Research Trust. Nationally wide, CoRT is one of the programs supposed to help teachers teach creative and critical thinking. Debono (2004) mentioned that he developed strategies and techniques for teaching creative and critical thinking skills for students known as the Cognitive Research Trust (CoRT) with the first CoRT thinking lessons published in 1974. According to Debono, CoRT Program consists of over sixty lessons focusing on developing students' creative and critical thinking skills. This program consists of six books, each one includes 10 lessons for teaching the following: Breadth, Organization, Interaction, Creativity, Information and Feeling and Action.

This study tackles the effect of teaching Creativity on the gifted learners. Gifted learners have high performance in intellectual, creative and specific academic areas. They are considered to be academically advanced because they learn fast and have advanced language skills, they have high degree of motivation and they need special instruction or services in order to develop their capabilities (Dannis, 2006; Tompkins and Hoskisson, 1991).

Problem, Purpose, Questions and significance of the study 
Research proved that there is an evident role for writing in enhancing the creative thinking abilities of writers. Simultaneously, educators are emphasizing the importance of teaching thinking skills in order to help students be better thinkers (Bear, 1988; Cotton, 1997; Morgan and Foster, 1999; Newton, 2000; Oslon, 1984; Presseissen, 1988). Consequently, many researchers emphasize the importance of supporting students with enough writing tasks and activities in order to enhance their thinking and creative abilities (Bland and Koppel, 1988; Calkins, 1994; De Anda, 2002; Erkaya, 2005; Garvie, 1990; Verghese, 2004).

There is an obvious need for improving Jordanian school students' writing skills because students' level of proficiency is not good enough and their weakness in writing is still observable (Ababneh, 1996; Abed, 1990; AbuShihab, 1986; Al-Hasan, 2006; Batayneh, 1986; Harrison, Prator and Tucker, 1975; Magableh, 1997;). Despite the need for developing the students' writing skills, many Jordanian researchers found that English curricula in Jordan still use the deductive approach in teaching grammar rules and writing (see, for example, Al-Hishoush, 2006; El-Mustafa, 1988; Karsou, 2005; Saleh, 1990). As a result, we still need to provide the gifted learners with extra thinking courses or programs in order to develop their creative abilities and transform their imaginative thoughts in original written works.

The purpose of this study is to investigate the effect of teaching CoRT (4) entitled "Creativity" on the gifted learners' abilities to write original, flexible and fluent short stories using wordless picture books. More specifically, the authors seek answers to the following questions:

1. Are there any statistically significant differences $(\alpha \leq 0.05)$ in the mean scores of students' achievement in writing between the experimental and controlled group that could be attributed to teaching CoRT?

2. What is the effect of teaching CoRT program No (4) "Creativity" on developing the gifted learners' ability to write creative short stories in Ein El-Basha Center for Gifted Students?

The findings are potentially significant for the gifted students since they are expected to develop their fluency, flexibility and originality when writing creative short stories. Educationalists in the Jordanian educational context may reconsider the syllabus with regard to increasing the number and quality of writing activities.

\section{Definitions of Terms}

The Gifted Students

The gifted students in this study were classified gifted because they met the criteria of giftedness that were adopted by MOE in 2002. They had a grade point average higher than $90 \%$ in the basic materials in the sixth and the seventh grade classes. These students had got recommendation letters from their teachers, advisors as well as their principals regarding their achievement. They also had to pass a test held by the board in Ein El_Basha Center for Gifted Students.

\section{CoRT Program}

CoRT stands for Cognitive Research Trust that was written by Debono (2004) who included ten lessons in Breadth, Organization, Interaction, Creativity, Information and Feeling, and Action. The CoRT sections, which were applied in this study, are CoRT (4) "Creativity" and CoRT (1) "Breadth". Creativity consists of 10 lessons which are 1) Yes, No and Po, 2) Stepping Stone, 3) Random Input, 4) Concept Challenge, 5) Dominant Idea, 6) Define the Problem, 7) Remove Faults, 8) Combination, 9) Requirements 10) and Evaluation. Breadth consists of 10 lessons which are 1) PMI, 2) Consider All Factors, 3) Rules, 4) Consequence \& Sequel, 5) Aims, Goals and Objectives, 6) Planning, 7) First Important Priorities, 8) Alternatives, Possibilities, Choices: APC, 9) Decisions and 10) OPV: Other People Views (Debono, 2004).

\section{Wordless Picture Books}

The wordless picture books in this study are stories without words; their pictures convey meaning, present the main points in a narrative and transport the reader through pictures arranged in sequence.

\section{Previous Literature}

Recognizing and nurturing students' talents and gifts present an important challenge to educators (see, for example, Han and Marvin, 2002; Smutny; 2000). In Jordan, the concern about the gifted students and providing them with enrichment activities began in 1980. Al-Maitah and Al-Bawaleez (2004) indicated that an institution in Salt adapted a private venture to discover the gifted students in the secondary stages in the schools. The concern about the giftedness in Jordan is still emphasized in different meetings and occasions. The First Council of Educational Development held in 1987 recommended verifying teaching methods to look after the gifted and creative students. The Ministry of Education (MOE) in its formal letters (mandated in 2002) emphasized the importance of preparing enrichment activities, lectures and meetings for the gifted learners. In addition, MOE considers developing the creative abilities as one of the most primary roles for the centers and the schools for the gifted.

Researchers stress that CoRT is one of the rare programs for developing the creative and the critical abilities of the students in various school subject matters (see, for example, Davis, 2002; Morgan and Foster, 1999). Creative and critical language learners are defined in terms of the learners' cognitive abilities to carry out certain tasks effectively. The creative language learners should be able to combine responses or ideas in novel ways (Smith, Ward and Finke, 1995), and to use elaborate, intricate, and complex stimuli and thinking patterns (Feldman, 1997). As for the critical language learners, they must be able to carefully and deliberately determine to accept, reject or suspend judgment about a claim (Moore and Parker, 1986). Because CoRT is a well known program for teaching creative and critical thinking 
skills, it is expected that the gifted students will develop their creative abilities in writing short stories in English by studying the CoRT thinking lessons.

In a study about the effect of using CoRT No.1 on developing creative thinking skills of eighty adult volunteers who were native speakers of English, Burke (1984) reported that there were significant differences in developing verbal fluency, verbal flexibility and verbal originality for students in the experimental group. In a another study about the effect of using CoRT 1 "Breadth", 2 "Organization" and 4 "Creativity" on developing the creative thinking of the fourth year students in UNRWA Educational Sciences College in Amman, Nofel (2006) reported that teaching CoRT developed the students' originality, flexibility and fluency.

Many researchers recommend writing short story because short stories enhance and emphasize the use of creative thinking (Bland \& Koppel 1988; De Anda, 2002; Erkaya, 2005; Garvie, 1990). However, many students are not encouraged to write them and the lack of creativity is obvious in their writing (Ellis, 2003; Schneider, 2006). Thus, it seems necessary to provide such groups of students with enough opportunities to practice and express their creative abilities in writing stories.

In a study about the effect of using CoRT 1 on developing the writing of 111 students' who attended Alabama University in the second semester in 1991, Hinnant (1993) reported that that there were significant differences in developing the students' writings in favor of the experimental group over the control one. The previous studies show that there is an effect for implying CoRT in teaching creative thinking skills for different groups of people. Such studies showed that creative thinking skills can be taught to students. However, there is still a need to conduct other studies in order to find out the role of teaching CoRT in developing the gifted learners' creative thinking and their abilities to write creative short stories using wordless picture books. This present study is considered as an extension for the previous investigations of teaching the cognitive and thinking skills. However, it takes a different path in its investigation by trying to find out how CoRT can be an important factor in developing high intellectual skills of gifted students in writing creative short stories.

It is believed that wordless picture books have the power to facilitate the process of teaching languages and the potentials to improve students' reading skills, their imagination, their creativity, their sensitivity to writing styles and expressive wordless modes (Carter, et al, 1998; Henry, 2003; Holmes, 1987; Khwaileh, 1991; McGee and Thompkins, 1983; Whalen 1979). Henry (2003) explained the role of wordless picture books in stimulating students' creativity to look more closely at story details, to carefully consider all story elements and to more clearly understand how to organize the learners' text so that a story develops. Henry found that students who used wordless picture books were able to build their reading and writing skills and strategies to ultimately produce a unique book.

Although some researchers claim that wordless picture books are more appropriate to be used by children, it is also claimed by others that wordless picture books can be used with different learners of different ages and levels of different English language proficiency (Cassady, 1998; D’ Angelo 1979; Houp, 2003; Jalongo etal, 2002; Russell, 1996). Nevertheless, that importance and great significant value of wordless picture books as well as their real importance have not been recognized in writing classes, yet.

In a study about creative writing of middle class students in Marco Polo Education Foundation in USA through wordless picture books, Henry (2003) stated that students explored various wordless picture books. They developed oral and written story lines for wordless picture books and they also developed critique story lines for peers. The researcher found that wordless picture books develop students' writing skills as well as their creative writings. In a study about the different demands of scripted and unscripted story writing task of 253 stories produced by 145 Scottish children in four schools from different local authorities and the extent to which the task prompts pupils to adopt different writing behaviors and attitudes, Ellis (2003) reported that the picture-sequence and modeled-story tasks provided ready-made decisions about the characters, events direction and the boundaries of the story. Pupils had few problems generating the basic story line or keeping it on track because the task had scripted this. This study showed that creativity and imagination could be taught and developed. Unscripted stories produced the most complex story structures although the structural support provided by scripted story tasks produced more consistent results.

The previous studies investigated the effect of using CoRT Program on developing the students' thinking skills and their writing skills. They also investigated the effect of using wordless picture books on developing the students' writing ability and their thinking skills in an attempt to prove the role of wordless picture books in developing the students writing skills. However, this study is different from the other studies since it studies the role of teaching CoRT "Breadth" and "Creativity" on developing the gifted students' ability to write creative short stories based on the given wordless picture books in the English language. This study studies the effective role of using wordless picture books as a means of revealing the gifted learners' creativity while writing creative short stories in the English language.

\section{METHOD AND PROCEDURES}

This research is essentially quantitative. The sample of the study consisted of all male and female students in the tenth and eleventh grades in Ein El-Basha Center for Gifted Students during the second semester of the academic year 2006/ 2007. The participants consisted of 25 students in the tenth grade and 11 students in the eleventh grade. The participants included 16 male students and 20 female students who were classified as gifted according to the criteria of 
giftedness which are adopted by the Ministry of Education. The students were divided randomly into control and experimental groups of equal size. Table 1 shows the number of the male and female students participated in the study.

TABLE 1

DISTRIBUTION OF SUBJECTS IN THE SAMPLE

\begin{tabular}{|l|l|l|l|l|l|l|}
\hline \multirow{2}{*}{ Grade } & Experimental Group & Control Group & \multicolumn{2}{l|}{ Total } \\
\cline { 2 - 8 } & Female & Male & Female & Male & Control & Exp. \\
\hline $10^{\text {th }}$ & 6 & 6 & 7 & 6 & 12 & 13 \\
\hline $11^{\text {th }}$ & 2 & 4 & 1 & 4 & 6 & 5 \\
\hline Total & 8 & 10 & 8 & 10 & 18 & 18 \\
\hline
\end{tabular}

The researchers developed an instrument which they used as a pretest and a posttest for both the experimental and control groups. The pretest consisted of a wordless picture sheet in the form of a series of eight pictures arranged without any text in order to test the students' fluency, flexibility, and originality in writing creative short stories. These pictures presented the main events of the story and conveyed meaning for the reader through pictures only. The topic of the series of pictures was about "Keeping Fit" which was adopted from Jones's article (2001) about raising approaches to the teaching of conversational story telling skills.

Students were encouraged to write stories of about 150 words at least and they were asked to generate their creative events using unexpected solution and several opening sentences to attract readers into their fictitious world. They were asked to generate their own story elements (fictitious characters, setting, meticulously developed events and creatively resolved climax). They were also asked to suggest creative and unexpected solutions. Simultaneously they were asked to generate coherent events in an appropriate and creative language.

The pretest results were evaluated according to the evaluation scale of the gifted learners' creative short stories which was developed by the researchers. The scale consisted of 15 points which aimed at measuring students' fluency, flexibility and originality in writing short stories. The scale describes four levels of students' creativity in English short stories: very good, good, accepted and poor levels. Both of the pretest and the evaluation scale were revised by a group of judges.

A panel of judges (three teachers of English, a supervisor of English, a headmistress of gifted learners' center, six university EFL professors and six university professors of special education) helped to validate the appropriateness of the tested linguistic items, the suitability of the test wording, the suitability of criteria wording and the suitability of the criteria items to measure creativity instruments of the study. The judges suggested more recommendations regarding the use of language or the criteria of evaluating the gifted learners' short stories. All their recommendations were taken into account during revising the criteria of evaluating the short stories and the pretest. Validity and reliability of the instruments were established.

To establish the internal consistency, the test was applied on a pilot group of on 15 gifted learners in order to measure the students' originality, flexibility and fluency in writing creative short stories The students participated in the pilot study were also gifted students in Ein El-Basha Secondary School for Girls, they were classified gifted because they met the criteria of giftedness which are adopted by the Ministry of Education. They attended Ein El- Basha Center for Gifted Students for a number of courses but they left it for personal reasons. The students in the pilot study were asked to generate creative stories for the wordless picture book "keeping fit" in 50 minutes. They were given the wordless picture in the form of arranged pictures about the topic "keeping fit". Then, they were asked to write genuine stories of about 150 words at least in which they were to generate their creative events using unexpected solution and several opening sentences to attract readers into their fictitious world.

Two teachers from different schools judged the students' creative writings. These teachers were teachers of English who had at least five years of teaching with a good experience in teaching and evaluating students' writing. They were asked to follow the criteria of evaluation of the students' creative writings after they were trained to use the scale of evaluating the gifted students' stories.

Each creative story was evaluated by the two teachers and the researcher. The three evaluators were working independently. Mean scores for the three grades were analyzed for every creative story. In order to avoid any biases in scoring, the papers were given numbers not names. The correlation between the students' marks in fluency, originality and flexibility as well as the whole written creative short stories in the pilot studies was high and acceptable for the purpose of the study.

Reliability for the consistency of evaluators (the two teachers and the researcher) was also calculated in order to determine the reliability for the second instrument (evaluation scale). The evaluators' scores on fluency, flexibility and originality were used to determine the reliability of the criteria of evaluating creative short stories. The results indicated that the reliability for the consistency between the three evaluators was high and significant for the purpose of the study. The reliability ranged from .77 for (judge2- judge 3 ) to .87 for (judge1- judge 3 ). The overall reliability was .951 which means that the criteria of evaluating the gifted learners' creative short stories were reliable.

To conduct the study, consent was obtained from MOE for applying the experiment in the center, the schools and the participants themselves. The researcher randomly divided the 36 students from both grades into two equivalent groups. The first group that consisted of 18 students from the tenth grade and the eleventh grades was randomly assigned as the experimental group. The other 18 students from both grade levels were automatically assigned as the control group. 
Students in both groups were asked to generate creative stories for the wordless picture book "keeping fit" in 50 minutes. This task was considered the pretest for both groups. After applying the pretest, all of the students in both groups were taught the course "Creative Writing" by one of the researchers for four months. The time allotted for each lesson was 50 minutes. The same researcher asked the students of the control and experimental groups to write five creative stories for different wordless picture books. The researcher presented the wordless picture books for the students and directed some questions about them. After that, the students were asked to analyze the elements of the stories. Then, students worked in groups in order to write creative short stories based on the given pictures. Finally, the researcher asked some of the groups' leaders to read their stories in front of the class. The researcher corrected the students' creative stories after listening for their oral presentations and provided the groups with feedback. After the students started writing creative short stories, the students in the experimental group were taught 10 lessons from CoRT 1 "Breadth" and 10 lessons from CoRT 4 "Creativity". Moreover, Debono's activity cards that aim at teaching creative thinking, developing fluency, flexibility and originality and training the students to use thinking tools of CoRT that are part of the two programs were also used.

The implementation of the program lasted three months following the procedures detailed in "Breadth" and "Creativity". CoRT 1 "Breadth was taught first because it is the basic section which has to be applied before the other five sections. After finishing "Creativity" and "Breadth", the researcher applied the creative posttest on the experimental and the control groups. The same three evaluators who evaluated the pretest evaluated the creative stories in the posttest. They used the same criteria of evaluating the creative stories in the pretest. Mean scores were analyzed for every creative story. After applying the posttest, the results of the pretest and the posttest were quantified in order to be compared for the sake of fluency, flexibility and originality and to find out if there were statistically significant effects of teaching CoRT 4 "Creativity" on the gifted learners' ability to write creative short stories.

\section{FINDINGS AND DisCUSSION}

To answer the research questions, which seek to identify whether or not there are any statistical differences in the gifted learners' writings due to applying CoRT Program No (4) entitled Creativity, students' grades on fluency, flexibility and originality in the creative writing test were analyzed. The mean scores and the standard deviation of students' grades in fluency for the two groups were also analyzed. To compare between the mean scores of the experimental and the control groups, Analysis of Covariance (ANCOVA) was used; the results of the analysis are presented in Table 2.

TABLE 2:

ANALYSIS OF COVARIANCE (ANCOVA) FOR FLUENCY

\begin{tabular}{|l|l|l|l|l|l|}
\hline Source & Type III Sum of Squares & df & Mean Square & F & Level of Significance \\
\hline Average of Fluency & 15.635 & 1 & 15.635 & 57.091 & $.01 *$ \\
\hline Experimental & 1.886 & 1 & 1.886 & 6.886 & $.013^{*}$ \\
\hline Standard Error & 9.038 & 33 & 274 & & \\
\hline Corrected Total & 27.639 & 35 & & \\
\hline
\end{tabular}

The results of Analysis of Covariance (ANCOVA) revealed that there is a statistically significant effect of teaching CoRT 4 on the gifted students' fluency in favor of the experimental group. Adjusted means, standard errors, confidence interval, raw scores and standard deviation of fluency by group were also analyzed for the control and experimental groups in order to find out if there were any statistically significant effects of teaching CoRT 4 "Creativity". The results are in Table 3.

TABLE 3:

\begin{tabular}{|c|c|c|c|c|c|c|}
\hline \multirow{2}{*}{ Group } & \multirow{2}{*}{$\begin{array}{l}\text { Adjusted } \\
\text { Mean }\end{array}$} & \multirow{2}{*}{ Std. Error } & \multicolumn{2}{|c|}{$95 \%$ Confidence Interval } & \multirow{2}{*}{ Mean } & \multirow{2}{*}{$\begin{array}{l}\text { Standard } \\
\text { Deviation }\end{array}$} \\
\hline & & & Lower Bound & Upper Bound & & \\
\hline Experimental & 7.813 & .124 & 7.562 & 8.064 & 7.87 & .89 \\
\hline Control & 7.354 & .124 & 7.102 & 7.605 & 7.30 & .81 \\
\hline
\end{tabular}

The adjusted mean of the experimental group was higher than adjusted mean of the control group which indicates that CoRT 4 contributed to the development of the experimental group's fluency in writing creative short stories. The results indicated that CoRT developed the students' ability to expand, support and elaborate on their ideas by giving helpful details. This means that CoRT developed the students' ability to produce logically cohesive and organized sentences, to produce a variety of sentence lengths, to show better command of the physical description of the characters and broad command of new effective words and idioms.

The Analysis of Covariance (ANCOVA) for the sum of mean scores of the experimental and control groups on flexibility was also analyzed in order to find if there was a statistically significant effect for CoRT 4 on the gifted students' achievement in flexibility in writing creative short stories. The results of this analysis are presented in Table 4. 
TABLE 4:

ANALYSIS OF COVARIANCE (ANCOVA) FOR FLEXIBILITY

\begin{tabular}{|l|l|l|l|l|l|}
\hline Source & Type III Sum of Squares & Df & Mean Square & F & Level of Significance \\
\hline Average of Flexibility & 30.450 & 1 & 30.450 & 155.328 & $.03 *$ \\
\hline Group & 4.664 & 1 & 4.664 & 23.789 & $.00 *$ \\
\hline Error & 6.469 & 33 & .196 & & \\
\hline Corrected Total & 39.515 & 35 & & & \\
\hline
\end{tabular}

The results of the Analysis of Covariance (ANCOVA) show that there is a statistically significant effect of CoRT 4 on the gifted students' achievement in flexibility in favor of the experimental group. Adjusted means, standard errors, confidence interval, raw scores and standard deviations of fluency by group were also computed and the results are revealed in Table 5 .

TABLE 5:

AdJUSTED MEANS, Standard ERRORS, CONFIDENCE INTERVAL, RAw MEANS AND STANDARD DEVIATION OF FLEXIBILITY By GROUP

\begin{tabular}{|c|c|c|c|c|c|c|}
\hline \multirow{2}{*}{ Group } & \multirow{2}{*}{$\begin{array}{l}\text { Adjusted } \\
\text { Mean }\end{array}$} & \multirow{2}{*}{ Std. Error } & \multicolumn{2}{|c|}{$95 \%$ Confidence Interval } & \multirow{2}{*}{ Mean } & \multirow{2}{*}{$\begin{array}{l}\text { Standard } \\
\text { Deviation }\end{array}$} \\
\hline & & & Lower Bound & Upper Bound & & \\
\hline Experimental & 7.630 & .105 & 7.417 & 7.843 & 7.54 & 1.18 \\
\hline Control & 6.907 & .105 & 6.694 & 7.120 & 7.00 & .89 \\
\hline
\end{tabular}

The adjusted mean of the experimental group was higher than the adjusted mean of the control group in flexibility which indicates that CoRT developed the gifted learners' flexibility in writing creative short stories. This indicates that CoRT developed the gifted learners' ability to produce a variety of ideas, to use correct time sequences and rhetorical devices appropriately and to reveal better control of complex structure and meaningful dialogues. The Analysis of Covariance (ANCOVA) for the comparison of the mean scores of the experimental and control groups on originality was computed and the results are shown in Table 6.

TABLE 6:

ANALYSIS OF COVARIANCE (ANCOVA) FOR ORIGINALITY

\begin{tabular}{|l|l|l|l|l|l|}
\hline Source & $\begin{array}{l}\text { Type III Sum } \\
\text { of Squares }\end{array}$ & Df & Mean Square & F & Level of Significance \\
\hline $\begin{array}{l}\text { Average of } \\
\text { Originality }\end{array}$ & 24.131 & 1 & 24.131 & 103.298 & $.00 *$ \\
\hline GROUP & 1.020 & 1 & 1.020 & 4.367 & $.044 *$ \\
\hline Error & 7.709 & 33 & .234 & & \\
\hline Corrected Total & 33.333 & 35 & & & \\
\hline
\end{tabular}

The results of Analysis of Covariance (ANCOVA) revealed that there was a statistically significant effect of CoRT 4 on the gifted students' achievement in originality in favor of the experimental group. Adjusted means, standard errors, 95\% Confidence Interval, raw scores and standard deviation of fluency by group were also analyzed and the results are revealed in Table 7 .

TABLE 7:

AdJUSTED MEANS, STANDARD ERRORS, CONFIDENCE INTERVAL, RAW MEANS AND STANDARD DEVIATION OF ORIGINALITY BY GROUP

\begin{tabular}{|l|l|l|l|l|l|l|}
\hline \multirow{2}{*}{ Group } & \multirow{2}{*}{ Adjusted mean } & \multirow{2}{*}{ Std. Error } & \multicolumn{2}{|c|}{$95 \%$ Confidence Interval } & \multirow{2}{*}{ Mean } & \multirow{2}{*}{ Standard Deviation } \\
\cline { 4 - 6 } & & & Lower Bound & Upper Bound & & \\
\hline Experimental & 6.613 & .114 & 6.381 & 6.845 & 6.65 & 1.1 \\
\hline Control & 6.276 & .114 & 6.044 & 6.508 & 6.24 & .86 \\
\hline
\end{tabular}

The adjusted mean of the experimental group was higher than the adjusted mean of the control group which shows that CoRT developed the experimental groups' originality. The results show that CoRT developed the gifted students' ability to use unpredictable events, unfamiliar titles and suitable solutions. Based on the results of the study, we can say that CoRT 4 could develop the gifted students' creativity and increased their ability to apply thinking skills while writing English short stories.

\section{Conclusions, Pedagogical Implications, ReCommendations And Limitations}

In conclusion, it seems that creativity can be taught using an appropriate program; the results of the study also showed that CoRT Program is an appropriate program which can stimulate the gifted learners' imagination and provide them with the suitable environment to develop their fluency, flexibility and originality while writing creative stories. This experimentation with CoRT encourages the hope that CoRT is vital and flexible enough for use in ESL classes in order to stimulate the students' creativity.

This indicated that CoRT developed the students' ability to expand, support and elaborate on their ideas by giving many helpful details. Many students were able to personalize their stories by giving names to the characters and places. Students showed better command of new effective words and idioms. Some students suggested several solutions for the 
climax, some students showed better command of the physical description of the characters. Students showed better flexibility by producing a wide variety of ideas. Students moved between familiar and imaginative ideas easily. Students were more able to write creative short stories using correct time sequence appropriately; students used past tenses to narrate the events of the stories, they used future tenses to express the characters' expectations and intentions and they used present tenses to describe characters and places. Students were more able to demonstrate knowledge of rhetorical devices such as simile, analogy and metaphor. Their stories were well organized with fewer errors. Some creative short stories evoked images and curiosity in the reader. They showed better control of complex structure and they produced accurate and meaningful dialogues. . Students were more able to build their writing skills to ultimately produce original stories; they were more able to build unpredictable events and infrequent ideas. They avoided clichés, formulas, stereotypes and predictable events by using ambiguity, gaps and openness. Many students suggested clever and unfamiliar titles for their stories such as "UFO". Many characters were well developed and shown instead of being told. Students' characters in their stories played active roles in dialogues instead of narrating their intentions and plans.

The findings of this study are consistent with previous research findings (cf., for example, Burke, 1984; Hinnant, 1993 Nofel, 2006) that CoRT developed students' flexibility, fluency and originality in their creative products. The findings of this study are consistent too with the findings of the studies conducted by Ellis (2003) and Henry (2003) that using wordless picture books helps students express their creative writing and produce unique writings, and that they have a positive effect on the students' writing skill, specific to the areas of sequencing and elaboration.

The highest degree of students' development was in fluency; the students' development in flexibility was higher than their development in originality. The lowest degree of development was in originality which could be due to the students' intension to produce familiar and known ideas and their need for more practice with thinking tools in order to develop their level of originality. Even though students' development in the three elements of creativity varied, there was a significant increase in all of the three elements. But how could one explain this increase? It may be assumed that CoRT taught the students how to imagine and express their creative ideas fluently. The amount of students' increase in mean scores indicates that the gifted learners learned the thinking skills from CoRT and then they were able to use such skill in their creative short stories writing.

Based on the findings of this study, researchers in special education are recommended to conduct similar studies to find out the effect of CoRT Program on other variables such as the gifted students' critical thinking, conduct similar studies on representative samples of gifted students in other centers and to try to find standardized tests for creative thinking in order to facilitate teaching and evaluating creative thinking. Furthermore, Text-books designers are recommended to design syllabuses for creative writing that focus on wordless picture books in language writing. Gifted learners' centers are recommended to adopt CoRT Program as a primary course in gifted learners' centers. Teachers are recommended to use pictures in the classroom because pictures stimulate and inspire creative writing and imagination.

This study examined all of the gifted students in the tenth and the first secondary grade in Ein El-Basha Center only, they were limited to (25) male and female students in the tenth grade and (11) male and female students in the first secondary grade in Ein El-Basha Center. The type of writing in this study was limited to creative short stories in the English language. CoRT Program sections that were applied in this study were CoRT one "Breadth" (the basic one) and CoRT four "Creativity". Writing creative short stories was limited to the creative short stories that were based on given pictures arranged in sequence in order to present the main points in a narrative.

\section{REFERENCES}

[1] Ababneh, S. (1996). Problems Facing EFL Jordanian Students in Expository Writing in Arabic and English. Unpublished Master's Thesis, Yarmouk University, Irbid, Jordan.

[2] Abed, F. (1990). The Effect of Feedback on the Writing Performance of Community College English Language Majors. Unpublished Doctoral Dissertation, The University of Jordan, Amman, Jordan.

[3] Abu- Shihab, I. (1986). The EFL Composing Processes of the Scientific Second Secondary Students in Jordan. Unpublished Master's Thesis, Yarmouk University, Irbid, Jordan.

[4] Al- Hasan, M. (2006). The Effect of a Proposed Conference Based Programme on DevelopingWriting and Critical Thinking Skills of Upper Basic Stage EFL Students in Jordan. Unpublished Doctoral Dissertation. Amman Arab University for Graduate Studies, Amman, Jordan.

[5] Al-Hishoush, A. (2006). A Context Analysis of Two National and International Textbooks in Jordan Based on Aspects in Teaching English. Unpublished Master's Thesis. Amman Arab University for Graduate Studies, Amman, Jordan.

[6] Al- Maitah, K. \& Al- Bawaleez, M. (2004). Al MawhebaWal- Tafawuk.(Giftedness and Excellence). (1st Ed). Amman: Dar Al_Fekr lelteba'ah Wal- Nasher Wal- Tawzee'.

[7] Batayneh, M. (1986). Contrastive Text Linguistic and Discourse Analysis Insights into Teaching Writing at Advanced Level with Special Reference to the Jordanian Context. Unpublished Master's Thesis. Univesity of Salford, Manchester, UK.

[8] Bear, J. (1988). Let's Not Handicap Able Thinkers. Educational Leadership, 45(7), 66-71.

[9] Bland, C. \& Koppel, L. (1988). Writing as a Thinking Tool. Educational Leadership, 45 (7), 58-60.

[10] Burke, G. (1984). Enhancing Adult Divergent Thinking Ability Using Edward DeBono's Method. Unpublished Dissertation Abstracts International, 45 (12), 3580.

[11] Calkins, M. (1994). The Art of Teaching Writing. Canada: Irwin Publishing.

[12] Carter, A, Holland, M, Mladic, L, Sarbeiwski, M. \& Sebastian, M. (1998). Improving Students Writing Skills Using Wordless Picture Books. Unpublished Master's Abstracts International, Saint Xavier University and IRI $\backslash$ Sky Light, Chicago. 
[13] Cassady, K. (1998).Wordless Books: No-Risk Tools for Inclusive Middle Grade Classrooms. Journal of Adolescent and Adult Literacy, 41(6), 428-432.

[14] Cotton, K. (1997). Teaching Thinking Skills, School Improvement. Research Series (SIRS). Retrieved May 12, 2005, from http:// www. nwrel. org $\backslash$ scpd $\backslash$ Sirs $\backslash 6 \backslash c u 11$. htm.

[15] Dannis, E. (2006). A Comparison of Traditional and Alternative Measure of "Giftedness" in Ministry Elementary School Children. Unpublished Dissertation Abstracts International, Fairleigh Dickinson University, New Jersey.

[16] Davis, C. (2002). Addressing Emotional Intelligence through the Teaching of Thinking Skills. Retrieved Nov 25, 2005 from http://www. Tag Conference 2000 Emotional Intelligence.htm.

[17] De Anda, Y. (2002). Wordless Picture Books Versus Standard Stories for Language Assessment of Spanish- Speaking Children. Unpublished Master's Abstracts International. The University of Texas- Pan America, Texas.

[18] D’ Angelo, K. (1979). Wordless Picture Books: Also for the Writer. Journal of Language Arts, 65 (7), 813-814.

[19] Debono, E. (2004). Edward de Bono Authorized Website. Retrieved February 12, 2004 from http://www.edwdebono.comldebonolindex.html.

[20] Ellis, S. (2003). Story-Writing Planning and Creativity, Reading, Literacy and Language, 37 (1) 27-31.

[21] El- Mustafa, A. (1988). An Evaluation of the TEFL Text Book (PETRA) for the First Preparatory Class in Jordan. Unpublished Master's Thesis, Yarmouk University, Irbid, Jordan.

[22] Erkaya, R. (2005). Benefits of Using Short Stories in the EFL Context. Asian EFL Journal, v8. Retrieved November 5, 2011 from http://asian-efl-journal.com/teaching-articles/2005/11/05/benefits-of-using-short-stories-in-the-efl-context.

[23] Feldman, S. (1997). Essentials of Understanding Psychology. New york: The McGraw Hill Company.

[24] Garvie, E. (1990). Story as Vehicle: Teaching English to Young Children. Clevedon: MultiLingual LTD.

[25] Han, K., \& Marvin, C. (2002). Multiple Creativity? Investigating Domain- Specificity of Creativity in Young Children. Gifted Child Quarterly, 46 (2), 98-109.

[26] Harrison, W., Prator, C., \& Tucker, R. (1975). English Language Policy Survey of Jordan: A Case Study in Language Planning. (1stEd). Virginia: the Center of Applied Linguistics.

[27] Henry, L. (2003). Creative Writing Through Wordless Picture Books. Educational Resource Information Center (ERIC). ED 477997.

[28] Hinnant, B. (1993). A study of Debono's PMI Thinking Tool as a Means of Enhancing Student Writing Performance. Retrieved Oct 27, 2004, from http://www. eric. ed. gov.

[29] Holmes, C. (1987). Children's Inferences with Print and Pictures. Journal of Educational Psychology, 79 (1), 14-18.

[30] Houp, R. (2003). There and Back Again: a brief Survey of Wordless Picture Books. Unpublished Master's Abstracts International. University of Florida, Florida.

[31] Jalongo, M., Dragich, D., Conrod, N. \& Zhang, A. (2002). Using Wordless Picture Books to Support Emergent Literacy. Early Childhood Education Journal, 29 (3), 167-177.

[32] Jones, J. (2001). A Consciousness - Raising Approach to the Teaching of Conversational Story Telling Skills. ELT Journal. 55 (2), 155-163.

[33] Karsou, M. (2005). An Evaluation of Action Pack Text Books as Perceived by Language Supervisors, Teachers and Students. Unpublished Master's Thesis, the University of Jordan, Amman, Jordan.

[34] Khwaileh, F. (1991). A Comparative Study of the Effects of Some Selected Prewriting Activities on the Quantity and Quality of Paragraphs Written by Ninth Grade Students in Ramtha. Unpublished Master's Thesis, Yarmouk University, Irbid, Jordan.

[35] Magableh, F. (1997). An Investigation of the Instructional Context of Writing development in Jordanian Primary Schools. Unpublished Doctoral Dissertation, University of Bristol, England.

[36] McGee, L. \& Thompkins. G. (1983). Wordless Picture Books are for Older Readers, too. Journal of Reading. 27 (2), $120-132$.

[37] Moore, N. \& Parker, R. (1986). Critical Thinking. California: Mayfield Publishing Company.

[38] Morgan, M. \& Foster, J. (1999). Creativity in the Classroom. Gifted Education International, 14 (1), $29-43$.

[39] Newton, P. (2000).Teaching For Understanding: What It Is and How To Do It. (1st Ed.). London: Routledge Falmer.

[40] Nofel, M. (2006). Athar Barnamaj CoRT fee Tanmeat Al- Tafkeer Al-Ebda'ee Lada AienahMen Al- Mutafawegeen tahseelian Fee Kulliat Al- Oloom Al-Tarbaweah Al- Jame'ah. (The Effect of CoRT Program on Developing the Creative thinking for a Sample of Excellent Students in Educational Sciences College). Paper presented at the First Arab Conference for CoRT Experts, Meredian Hotel, Amman, 19-20, July, 6-48.

[41] Oslon, B. (1984). Fostering Critical Thinking Skills Through Writing. Educational Leadership, 42 (3), 28-39.

[42] Presseisen, Z. (1988). Avoiding Battle at Curriculum Gulch: Teaching Thinking and Content. Educational Leadership, 45 (7), 7- 8.

[43] Russell, G. (1996). Reconceptualising Pedagogy: Students’ Hypertext Stories with Pictures and Words, Ed Tech 96 Biennial Conference of the Australian Society for Educational Technology, Australia.

[44] Saleh, M. (1990). An Evaluation of the TEFL Text Book (PETRA) for the Second Preparatory Class in Jordan. Unpublished Master's Thesis. Yarmouk University, Irbid, Jordan.

[45] Schneider, D. (2006). Class Novels and Creative Writing. American Library Association\Book Link, 45- 46.ED 203093191.

[46] Smith, M., Ward, B. \& Finke, A. (1995). The Creative Cognition Approach. Cambridge MA: Bradford.

[47] Smutny, F. (2000). Teaching Gifted Children in the Regular Classroom. Retrieved May 1st, 2000 from http://www.Eric.ed.gov.

[48] The Ministry of Education. (2002). The Meeting of the Centers of the Gifted and Talented Students. Document No.68\13, Amman, Jordan.

[49] The Ministry of Education. (2003). The General Framework for Curricula and Evaluation, Amman, Jordan. P1- 6.

[50] The Ministry of Education. (2002). The Criteria of Selecting Gifted Students for Pioneers Centers. Document No. 14 12 12, Amman, Jordan.

[51] Tompkins, G. and Hoskisson, K. (1991). Language Arts: Content and Teaching Strategies. (2nd ed.). New York: Macmillan Publishing Company.

[52] Verghese, V. (2004). Creativity in English Language Teaching. (1st Ed). New Delhi: Anmol Publications PVT. LTD. 
[53] Whalen, L. (1979). Wordless Picture Books: Every Picture Tells a Story, Doesn’t it? Emerging Librarian, 21 (5), 14-17.

Oraib Hmoud Al-Faoury is an assistant professor of translation courses, TEFL and CALL in the English Language Department at Al-Imam Mohammad ibn Saud Islamic University $\backslash$ Riyadh. She has been teaching English at different colleges and universities for more than ten years. She has written and published research in creative short stories, giftedness, The Multiple Intelligence Theory, child rights and Whole Language Approach.

Faisal Khwaileh is an associate professor of Methods of Teaching English as a Foreign \Second Language. He has been teaching BA, Diploma, and Graduate Courses since 1999. He is now teaching graduate courses and supervising MA and Ph D students in the Department of Curriculum and Instruction at The University of Jordan - Amman, Jordan. His research interests include Second Language Acquisition, TEFL, Discourse Analysis and Pragmatics, and curriculum of English Language. 